Pripremni radovi za planiranje prostornog razwoja grada Zagreba u razdoblju izmedu 1981-1985. godine

GRAD ZA RUSENJE

Zagreb

Sanacija

Stanje, problemi i mogucnosti

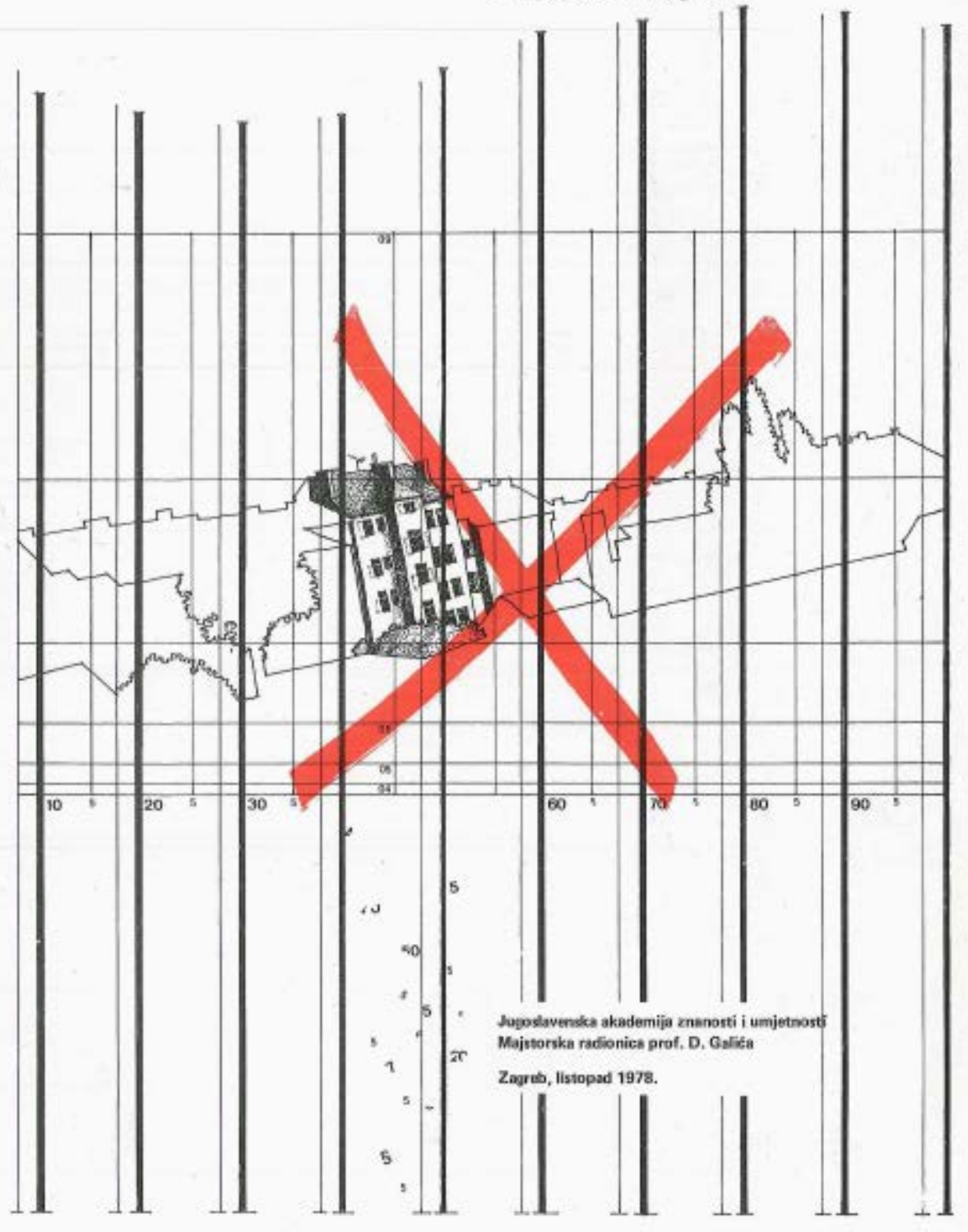




\section{Ponešto o kontejnerima u privremenoj arhitekturi O}

DOI: 10.31664/zu.2020.107.08

Elementarne nepogode, poplave, potresi i pandemija, ponovno su izazvale zanimanje za kontejnersku arhitekturu-Gunja 2014., koronavirus u Hrvatskoj, potres u Zagrebu i potresi na Baniji 2020.

Danas jedan stambeni kontejner košta oko 67.000,00 kn plus PDV, što ukupno iznosi $83.750,00 \mathrm{kn}$, odnosno $11.166,00$ EUR. Takav kontejner od $18 \mathrm{~m}^{2}$ stoji 620,00 EUR po $\mathrm{m}^{2}$ ili 4.650,00 kn po $\mathrm{m}^{2}$. Skupo ili jeftino? Isplativo ili ne? Za što i gdje je pogodna takva kontejnerska arhitektura?

Za točke testiranja koronavirusa pokazala se praktična. Za hitno zbrinjavanje osoba ugroženih elementarnim nepogodama, u slučaju da postoje u robnim rezervama, uz bok su kamp-kućicama koje također nisu zanemarive u izvanrednim situacijama. Kod Petrinje se upravo radi veliko kontejnersko naselje sa stambenim kontejnerima, vrtićem i nekim administrativnim potrebama. To se u ovim uvjetima može tolerirati, iako propisi za vrtiće i javne namjene ne dozvoljavaju tako male visine.

$\rightarrow$
Majstorska radionica profesora Drage Galića, Grad za rušenje. Zagreb. Sanacija. Stanje, problemi i mogućnosti. Zagreb: JAZU, I978.

\section{Boško Budisavljević}

Arhitekt i urbanist, Zagreb 

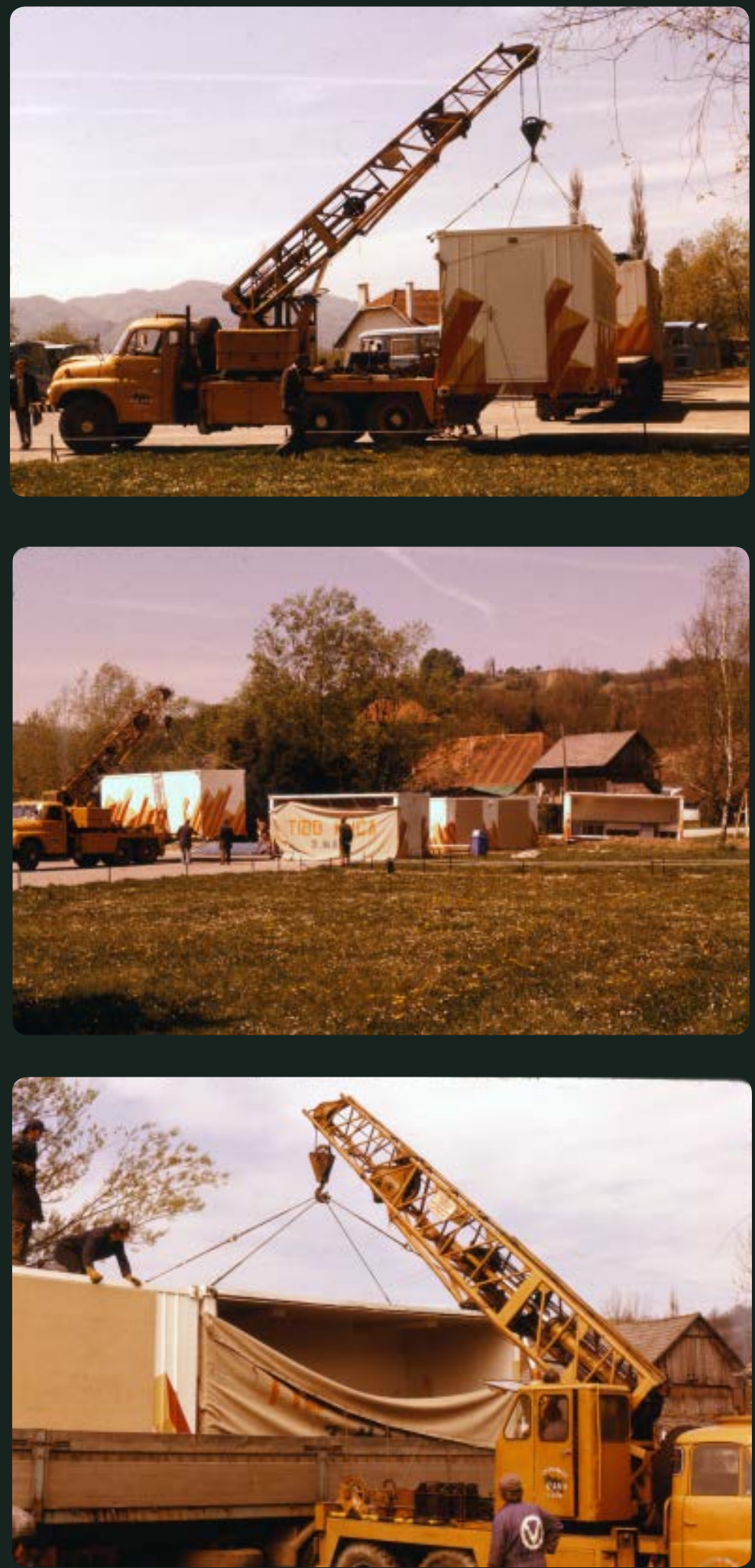
Kontejnerska arhitektura ima ograničenu primjenu. Njezina je prednost da može odmah reagirati u elementarnim nepogodama, ali nije dobro rješenje za razdoblja duža od nekoliko mjeseci. Slaba toplinska izolacija i ograničena visina koja se danas nudi nisu prikladni ni za duži stambeni smještaj, a još manje za javne sadržaje. Također, skladištenje i održavanje stambenih kontejnera u tzv. robnim rezervama zahtijeva velike površine i stalno održavanje i zaštitu. I stoga predstavlja mrtvi kapital. Sigurno je da i šatori imaju niz prednosti u izvanrednim slučajevima, a puno su jeftiniji, zauzimaju mnogo manje skladišnog mjesta i nema toliko opasnosti od propadanja.

Kad je novoformirani Stožer za sanaciju posljedica potresa u siječnju 2021.izjavio da bi gradnja tri tipska stambena objekta mogla započeti za šest mjeseci, pokazao je potpuno nepoznavanje materije. Dok Stožer s nadležnim fakultetima planira za projektiranje stambenih tipova (koji već postoje u tisućama varijanti) šest mjeseci, na ugroženim područjima mogao bi se u to vrijeme izgraditi velik dio potrebnih klasičnih i montažnih stanova i kuća.

Klasična gradnja ili kvalitetna montažna gradnja načelno su u prednosti. Po cijeni su slični, a nisu poput kontejnera ograničeni dimenzijama. Tlocrtnu površinu jednog kontejnera s temeljima, zidovima, stolarijom i prvom dekom grupa zidara izradi za tri dana. A taj se osnovni modul u klasičnoj gradnji može kasnije dozidavati i graditi u visinu po volji i potrebama, ničim ograničen.

Među montažnim načinima građenja spomenuo bih metodu engleskog arhitekta Waltera Segala (1907.-1985.). „Segal metoda” eliminira potrebu za mokrim zanatima poput zidanja i žbukanja. Princip je da se kupuju gotovi proizvodi koji postoje u svakom dućanu građevinskog materijala. Segalove kuće nemaju temelja, već se postavljaju na obične betonske ploče. Metoda „kupnje u trgovini” koja se primjenjivala u Segalovim kućama omogućila je da se, primjerice, jedna takva zgrada u Londonu, izgrađena 1988. godine, a 2012. predviđena za uklanjanje, demontira i ponovno postavi na novom mjestu.

U Hrvatskoj montažna izgradnja ulazi u širu upotrebu sredinom 1950-ih. Montažne zgrade zagrebačkog Jugomonta, zajedno s montažnim kućama doniranima iz Meksika, SSSR-a i Švedske, korištene su za smještaj stanovnika u potresu razrušenog Skoplja 1963. S druge strane, kontejnerske kuće ili kuće od kontejnera tek su u zadnje vrijeme postale zanimljive. U Hrvatskoj još nema nijedne, koliko znam, a u Sloveniji je nedavno jedna takva kuća postala hit. Magazin Gradimo Zadar (GZD) u rujnu 2020. donosi članak novinarke Nataše Rožić Mikolašević o kući koju je izradio (a ne izgradio) Uroš Horval, po struci strojarski tehničar. Kupio je rabljene brodske kontejnere u Grazu (jeftinije nego u Sloveniji) i od njih pet složio stambeni objekt. Prednost je u tome što nema mokre gradnje, ali je cijena slična cijeni klasične ili montažne gradnje. Dakle, rekli bismo, stvar ukusa. U svijetu ima više primjera arhitekture napravljene od brodskih kontejnera, ali to više pripada hiru i ekscentričnosti nego nekoj prednosti pred drugim vrstama gradnje. Moja iskustva s kontejnerskom arhitekturom datiraju iz 1970-ih godina. (SI. 1) Najvažnija među njima ostvarena su u suradnji s brodogradilištem, a realizirana u sklopu Majstorske radionice za arhitekturu Drage Galića.

Sl. I Isporuka kontejnera za snack-bar u Spomen-parku Kumrovec, I977. 
Majstorske radionice likovnih umjetnosti Jugoslavenske akademije znanosti i umjetnosti (danas HAZU) bile su jedno od onih mjesta gdje se moglo maštati, projektirati, crtati, kipariti i bilo što drugo što se učenicima (suradnicima) činilo važnim. Preuzeti sovjetski model, s određenim promjenama, funkcionirao je u Zagrebu od 1947. do 1984. Bio je zamišljen kao poslijediplomski studij pod mentorstvom majstora. Radionica za arhitekturu bila je u vili Ehrlich-Marić u ulici Ivana Gorana Kovačića 37. Od 1995. ondje se nalazi Hrvatski muzej arhitekture.

Po mojem sjećanju, najprije je to od 1952. bila Majstorska radionica arhitekta Drage Iblera, profesora Odjela za arhitekturu na Akademiji likovnih umjetnosti. Studij je bio paralelan s onim na tadašnjem Arhitektonsko-građevinskogeodetskom fakultetu (AGG). Razlika je bila i u tituli. Završeni studenti kod Drage Iblera bili su akademski arhitekti, a na AGG fakultetu diplomirani inženjeri arhitekture. Poznato je da su kod Iblera završili među ostalima Mladen Kauzlarić, Lavoslav Horvat, Neven Šegvić i Drago Galić. Kad sam se odlučio upisati na arhitekturu (1960. godine), mislio sam na onu na Likovnoj akademiji. Međutim, baš te godine taj je studij ukinut. Šteta.

U Majstorsku radionicu godišnje se primao mali broj suradnika, putem natječaja. Službeno su se suradnici tu usavršavali dvije godine, ali u praksi su ostajali i duže. Međutim, to nije nikada bio službeni poslijediplomski studij koji je priznavalo zagrebačko Sveučilište. Suradnici su nakon završenog usavršavanja dobivali jedan papir formata A4 na kojem je pisalo da su završili studij usavršavanja. Potpis „majstora arhitekta” i pečat Akademije znanosti i umjetnosti. Od 1964. do 1984. radionicu je vodio Iblerov student i dugogodišnji suradnik Drago Galić. Dok su kod Iblera suradnici razrađivali njegove projekte, kod Galića su imali slobodne ruke u izboru tema. Najveći broj suradnika radio je arhitektonske natječaje. Ne sjećam se da je itko osim mene i Ratka Miličevića radio druge vrste zadataka.

U Majstorsku radionicu primljen sam 1971. godine, nakon diplome kod profesora Galića s radom Stambena jedinica određene veličine. Proveo sam tamo više godina, i to u dva navrata. Prvi put od 1971. do 1973., a zatim od 1977. do 1979. Rad u Majstorskoj radionici smatram jednim od najzanimljivijih životnih razdoblja. Zašto? Zato što su to bili sretni dani posvećeni samo zadacima koje sam sam izmišljao. Svaki dan pješice ili tramvajem do Frankopanske pa šetnja kroz Tuškanac do Majstorske. Tamo je bila ekipa, svatko se bavio svojim zadatkom, miješala se hladna instant-kava za pauze. Profesor bi nas često obilazio i razgovarali bismo o projektima i uvijek ga zapitkivali nešto o njegovu radu. Mene je, recimo, zanimalo zašto su na njegovoj kući u Proleterskih brigada (danas Vukovarska 35-35A) kućice od lifta različite. Odgovorio mi je na to pitanje. I tako, svaki put nešto.

Istodobno sam radio kao istraživač na Arhitektonskom fakultetu u Zagrebu. Vrijeme provedeno na studiju u Parizu, gdje sam 1974. diplomirao na École Nationale Supérieure des Beaux-Arts s titulom „architecte D.P.L.G” (diploma koju potpisuje francuska vlada) s radom Način korištenja stana, proširilo mi je spoznaje i vidike pa mi povratak na zagrebački fakultet nije odgovarao.

Odlučio sam pokušati u Zaboku, gdje su tražili planera i gdje sam vidio mogućnost ostvarenja nekog drugačijeg pristupa prostornom planiranju. Tu sam uspostavio dobru planersku bazu koja je onda mogla funkcionirati i bez mene. Nakon toga zaintrigirala me ponuda Spomen-parka Kumrovec za organizaciju i planiranje rada i realizaciju nužnih sadržaja kojih tamo nije bilo, a četrdeset autobusa dolazilo je dnevno u posjet rodnom selu predsjednika Josipa Broza Tita. Ponuda je došla sa zagrebačkoga političkog vrha. Razlog je bio smjena tadašnje ekipe koja je vodila Spomen-park, a s kojom zagrebački vrh nije bio zadovoljan. Za direktora je postavljen jedan pukovnik u penziji koji je morao to riješiti politički (raspustiti kumrovečku organizaciju), a ja sam se trebao baviti realizacijom objekata

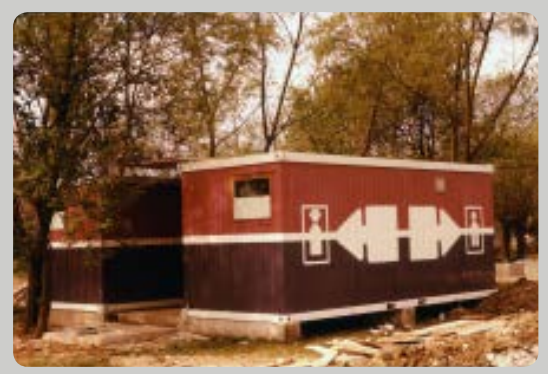

Sl. 2 Boško Budisavljević, Javni zahod u Spomen parku Kumrovec, I977.

$\uparrow$ 
i sadržaja koji bi bili primjereni Kumrovcu, odnosno Spomen-parku. Te 1977. godine tamo nije postojalo gotovo ništa. Ni javni WC-i, ni neki informacijski punkt, ni aktivnosti primjerene novoosnovanom parku. Funkcionirao je samo etnografski kompleks Staro selo, u kojem je bila Titova rodna kuća. I spomen-dom na brdu iznad Kumrovca dovršen 1974. godine.

SPOMEN-PARK KUMROVEC

Kako u kratko vrijeme osigurati osnovne sadržaje za funkcioniranje Spomenparka? Spomen-dom s kongresnim i društvenim centrom te hotelskim smještajem postojao je kao zasebna cjelina i upotrebljavao se za razne političke skupove i manifestacije. Sjajan projekt arhitekata Berislava Šerbetića i Ivana Filipčića. Za gradnju bilo kakvih „čvrstih” objekata trebalo je vremena, kojeg nije bilo. Za klasičnu proceduru, izradu projekta, ishodovanje dozvole i realizaciju trebalo je najmanje godinu dana. Tražio sam način kako da se nešto gotovo dopremi u Kumrovec, pokraj parkirališta. Naišao sam na oglas tvrtke Radgona iz Slovenije koja je izrađivala kontejnere za transport tereta (tzv. brodske kontejnere). Napravio sam projekt sanitarnog čvora, odnosno javnog WC-a koji je poštovao dimenzije kontejnera i zatražio sam ponudu. Već u prvim danima rada vidio sam da samo ime Spomenparka u Kumrovcu otvara sva vrata. Naručili smo dva kontejnera za javne WC-e, muški i ženski. Sjećam se jednog detalja-posebnog pisoara za djecu, nižeg od standardnih (teško da ćete to negdje drugdje naći osim u vrtićima). Također smo napravili poseban plan bojenja kontejnera s grafičkim elementima da bi objekt bio uočljiv i vizualno zanimljiv. Kontejneri su stigli za tjedan dana. Za Radgonu je to bio novi program u kojem su i oni vidjeli mogućnost nove ponude. (SI. 2)

Onda je na red došao nužni informacijski centar, jer se nigdje u Kumrovcu nije mogla dobiti nikakva informacija o Spomen-parku i Starom selu na jednom mjestu. Također, nije bilo nikakvog mjesta gdje se mogla dobiti čaša vode, sok, pivo i sendvič, nešto poput snack-bara. (SI. 3, 4, 5) Napravio sam projekte. Taj smo put zatražili ponudu brodogradilišta „3. maj” iz Rijeke, koji su isto proizvodili brodske kontejnere i jednostavne kontejnere za gradilišta. Dojurili su odmah iz Rijeke. Cijela delegacija. Rekli smo da trebamo informacijski centar, snack-bar s tendom i svlačionice uz sportske terene. (SI. 6) Bili su jako zainteresirani. Po mojim projektima, opet držeći se kontejnerskih gabarita, „3. maj” je u vrlo kratkom roku izradio, dopremio i montirao te objekte. Za Kumrovec je to bila revolucija. Konačno je postignut barem minimalni komfor za tisuće posjetitelja iz cijele Jugoslavije i inozemstva. I mi smo bili oduševljeni, jer nešto tako nikad nismo vidjeli. Pogotovo što smo se upustili u vrlo neobičan način bojenja tih kontejnera. Taj je zadatak sjajno riješio, nažalost, pokojni kipar Janez Segulin. Mislim da je „3. maj” više vremena utrošio bojeći kontejnere po Janezovim nacrtima nego što im je trebalo za izradu samih jedinica, što je za njih bio rutinski posao. Nakon tog uspjeha ponudili smo im izradu studije o mogućnostima i tipovima kontejnera za različite namjene. (SI. 7) Prihvatili su i potpisali smo ugovor. Ubrzo sam napustio Spomen-park i vratio se u Majstorsku radionicu. Profesor Galić opet je bio pri ruci i pomogao u regulaciji ugovora sklopljenog između „3. maja” i JAZU-a.
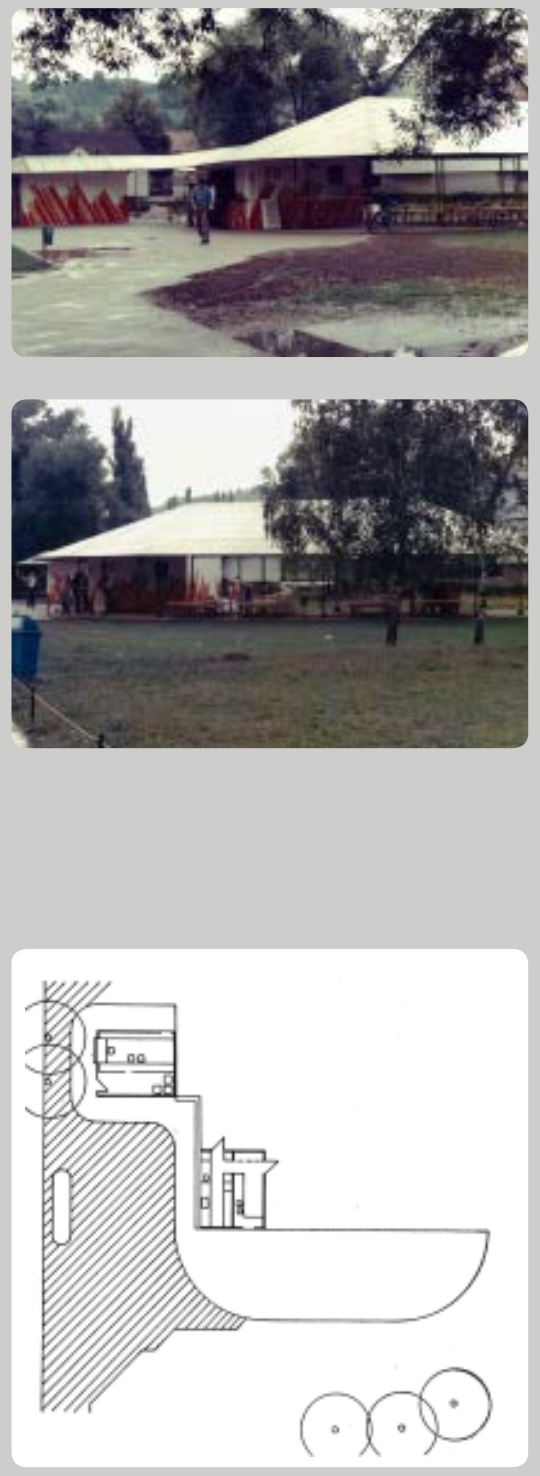

Sl. 3 Boško Budisavljević, Snack-bar i infocentar u Spomen-parku Kumrovec, 1977 . $\uparrow$ 

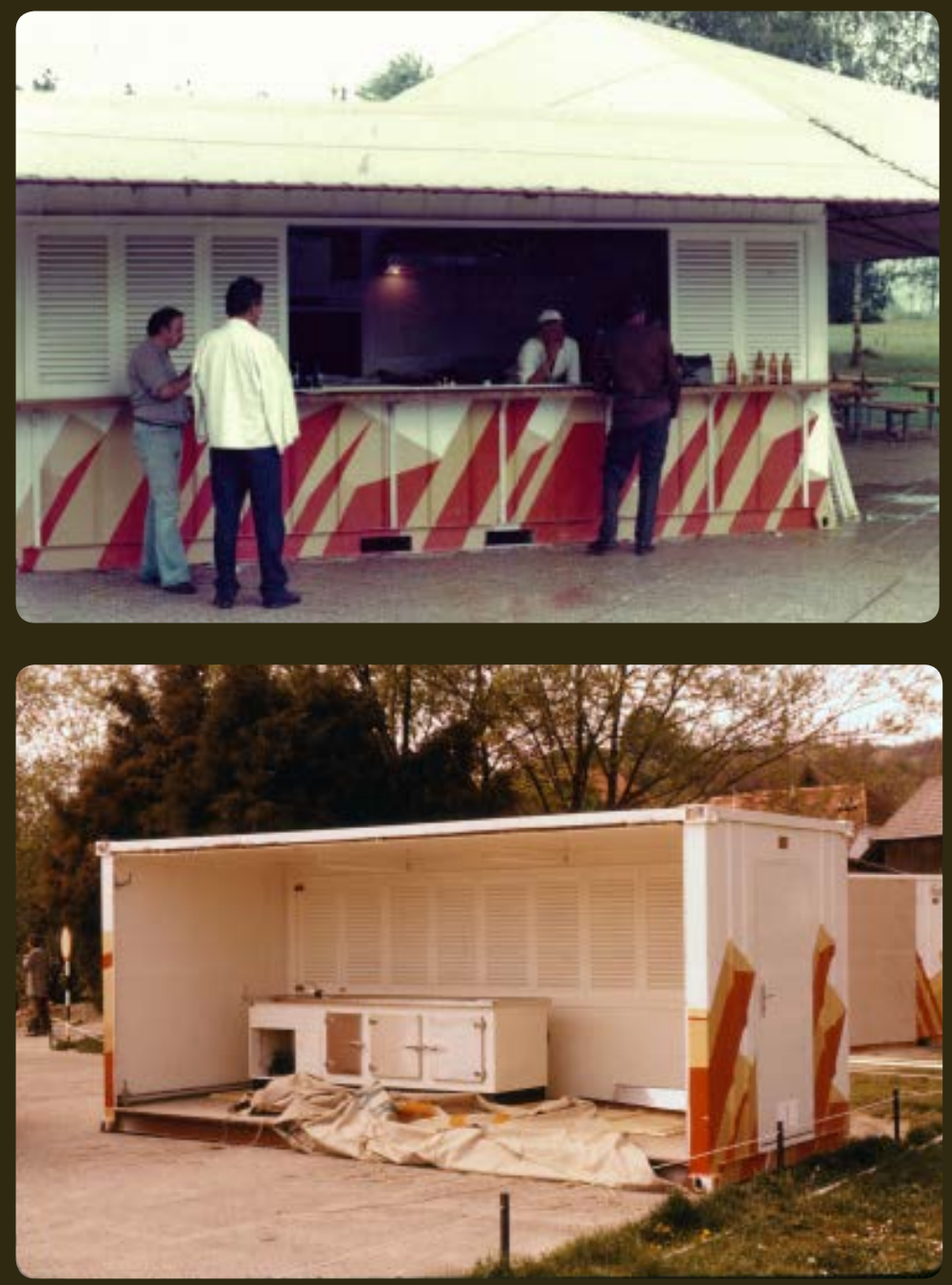

Sl. 4 Boško Budisavljević, Snack-bar u Spomen-parku Kumrovec, I977.

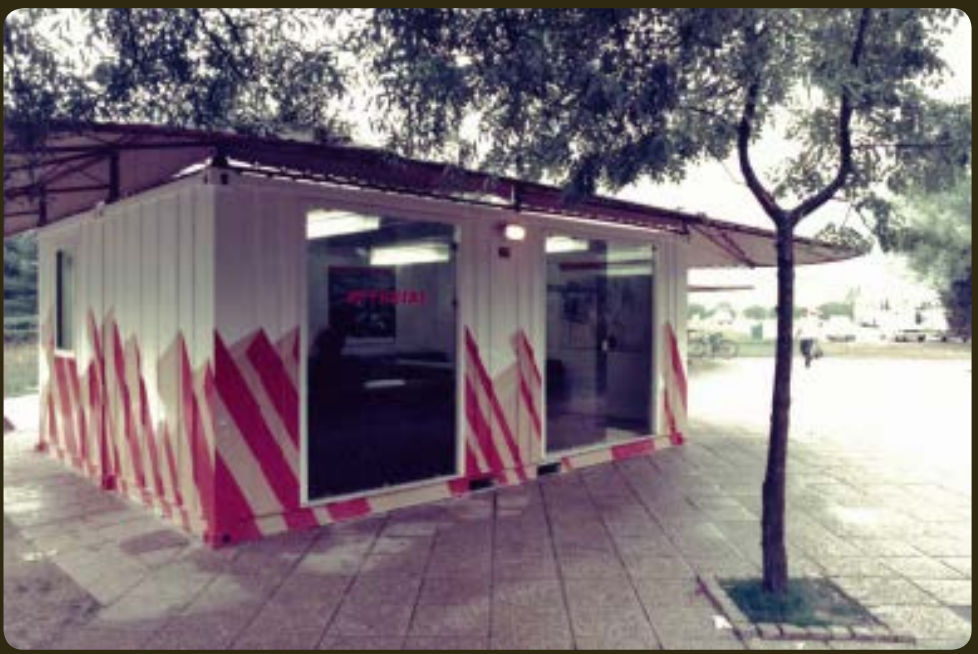

Sl. 5 Boško Budisavljević, Info centar u Spomen-parku Kumrovec, I977. 

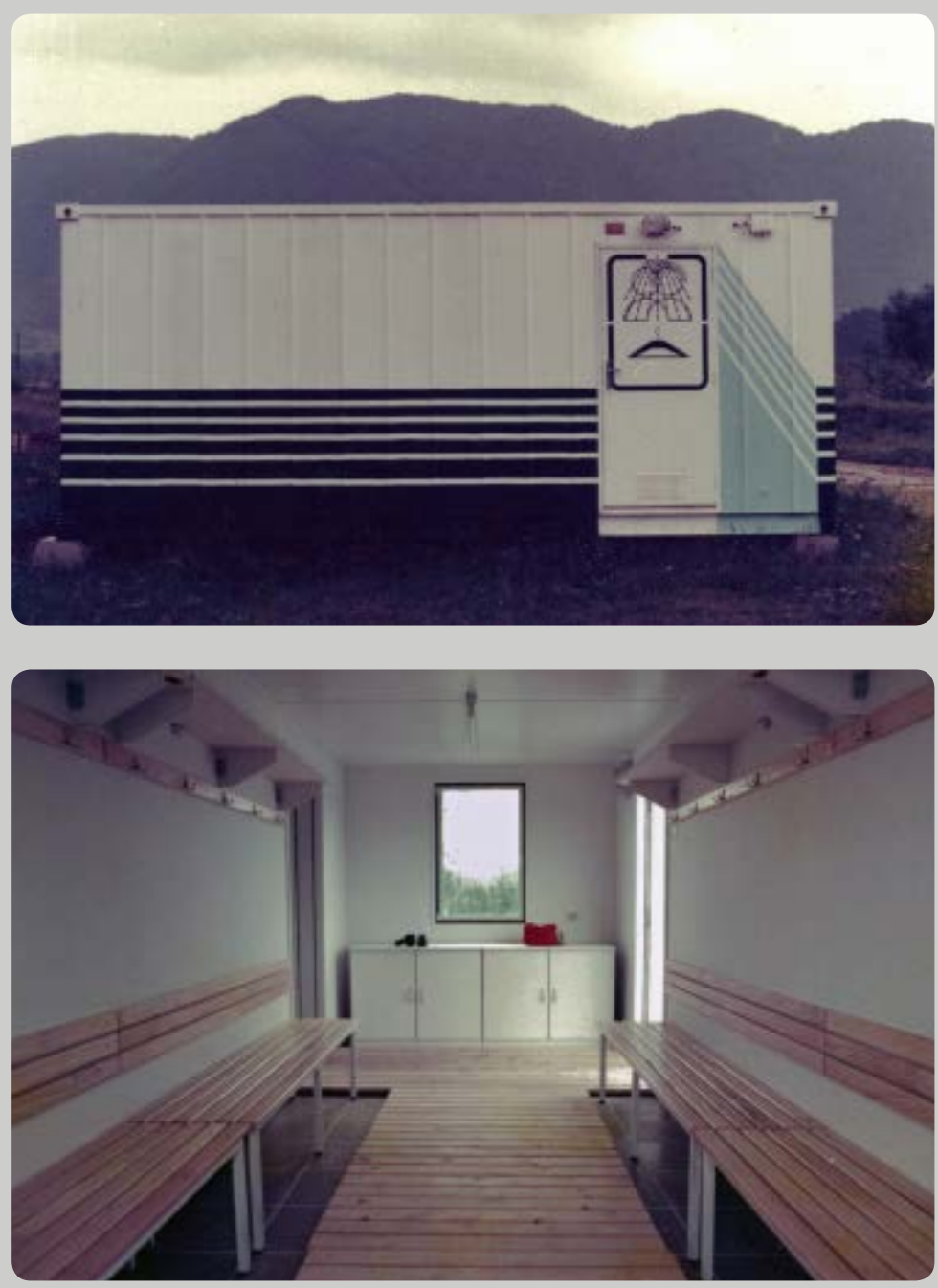

Sl. 6 Boško Budisavljević, Svlačionica u Spomen-parku Kumrovec, 1977. $\uparrow \downarrow$

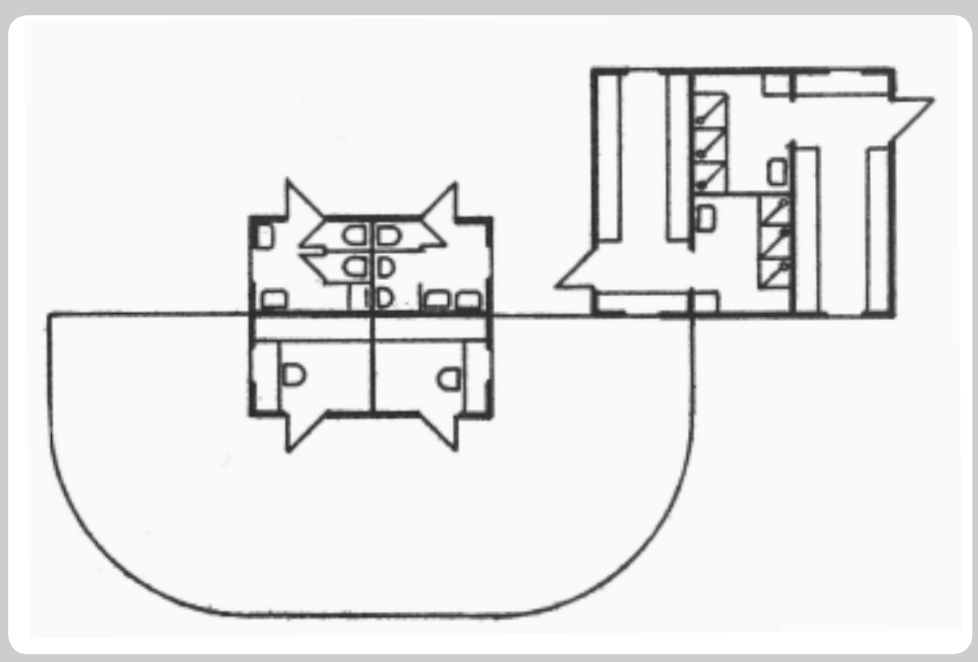



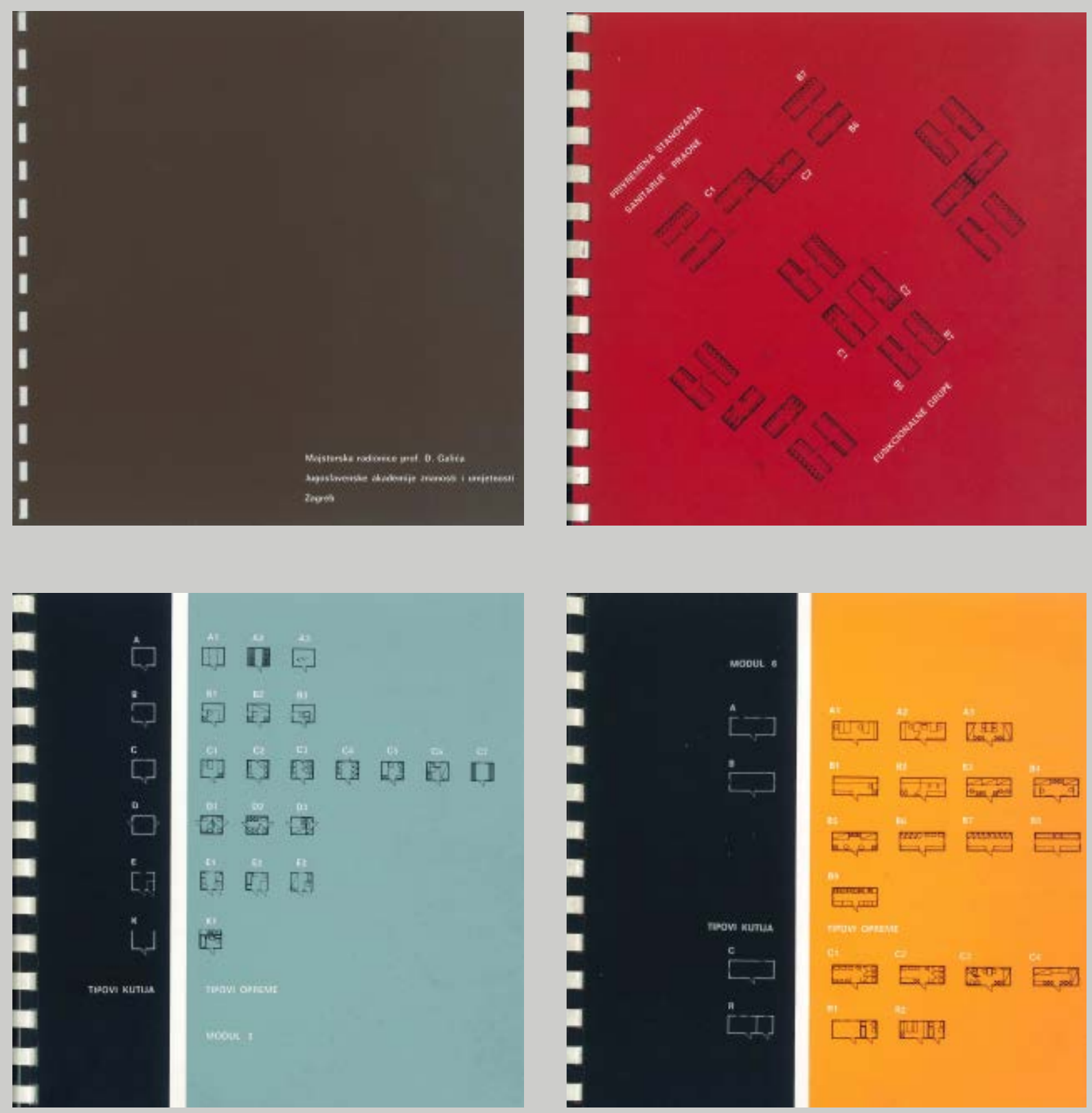
Boravili smo jedno vrijeme u „3. maju” kod sjajnog direktora Drage Babića. U to je vrijeme bila kriza u brodogradnji i on je na sve načine nastojao pokrenuti neku drugu proizvodnju, a prenosive jedinice učinile su mu se kao dobar poslovni potez. Autori i suradnici studije su bili Boško Budisavljević i Ratko Miličević (projekti), Filka Vigna (marketing), Hrvoje Devide i Janez Segulin (grafički dizajn). Istražili smo tržište, intervjuirali potencijalne kupce i izradili marketinšku studiju. Od 1977. do 1979. izradili smo dokumentaciju za niz mogućih varijanti u odnosu na veličinu modula i namjenu koje su izašle iz marketinške studije-stanovanje, uredski prostor, poslovni prostor, turizam itd. (SI. 9a, 9b) Program „3. maja” nazvan je TIBO kuća Beta po zasebnoj radnoj jedinici u okviru brodogradilišta-Tvornici industrijske i brodske opreme.

Program je omogućavao brzo i efikasno „slaganje” prostora za najrazličitije radne, poslovne i stambene potrebe spajanjem odabranih komponenti. Činio ga je odabrani broj tvornički proizvedenih komponenata i dodatne opreme. Postojale su četiri osnovne jedinice dužine od 1,2 m, 2,4 m, 3,6 m i 6,0 m, sve nastale umnažanjem osnovnog modula od 1,2 $\mathrm{m}$. Za javne sadržaje problem je bila standardna visina kontejnera od 2,35 m. To smo riješili s posebnim „kapama” od poliestera koje je moglo proizvesti brodogradilište „Greben” u Veloj Luci. Oni su se bili proslavili blokom sanitarnih čvorova od poliestera ugrađenih u jedan hotel u Veloj Luci. Izmjenjivim krovnim sekcijama postizale su se tri različite unutrašnje visine prostora od 2,35 m, 2,70 m i 3,0 m. Dodatni elementi bile su nadstrešnice-vezane za kontejner, slobodne nadstrešnice i tende. Sve jedinice bilo je moguće spajati u veće prostore bez obzira na različite visine. Također su postojale i stijene za ograđivanje kojima su se formirali vanjski prostori. Postojao je i poseban katalog komponenata. Prospekti su bili rađeni i po namjenama (turizam, poslovni prostor, funkcionalne grupe, stambeni prostor i dodatni prostor). (SI. 11) U odnosu na današnje domaće proizvođače „Tehnix” i „Jedinstvo” te druge montažne proizvode koji se nude, sustav TIBO Beta osmišljen i proizveden prvi put pred više od četrdeset godina čini se nedostižnim.

Program TIBO prvi put je izložen na Zagrebačkom velesajmu 1977. (SI. 8) Rad na kući TIBO nadahnuo je jedan naš drugi projekt također realiziran u Majstorskoj radionici-sanaciju zagrebačke periferije. (SI.10) Studiju slučaja proveli smo na Trnju u naselju Vrbici, prostoru bivših savskih rukavaca između Filozofskog fakulteta i "Raketa”, stambenog kompleksa na Zelenom trgu. To su bili dijelovi grada, uglavnom sa supstandardnim gradnjama, urbanističkim planovima predviđeni za rušenje. Samo se nije znalo kada. Stanovnici su bili blokirani i nisu smjeli ništa dograđivati. U jednoj je obitelji mladi bračni par očekivao podmladak. Mjesta u postojećoj kućici nije bilo, a nisu imali ni kupaonicu ni potrebnu sobu. U dogovoru s „3. majem” u Vrbik je dopremljen jedan stambeni kontejner od sobe, kuhinje i kupaonice. Dizalica ga je spustila u dvorište i mladi je bračni par rođenje djeteta doživio u novom prostoru. Nažalost, nakon mjesec dana morali smo vratiti tu prenosivu jedinicu. Od silnog uzbuđenja oko te akcije zaboravili smo to slikati, tako da to nije fotografski zabilježeno. Studija Vrbika donijela nam je nagradu 14. zagrebačkog salona 1977.

Uslijedila je narudžba Urbanističkog zavoda grada Zagreba-studija Grad za rušenje-Zagreb-Situacija-Stanje, problemi i mogućnosti rješavanja, naručena u sklopu pripremnih radova za planiranje prostornog razvoja grada Zagreba u okviru petogodišnjeg plana 1981.-1985. Studija je predlagala da se za gradske četvrti predviđene za rušenje dozvoli dogradnja postojećih stambenih objekata do gradskog prosjeka. To je bilo oko $20 \mathrm{~m}^{2}$ po osobi, odnosno izjednačeno sa standardom koji se propisivao za društvenu stambenu izgradnju. I za taj je projekt profesor „sredio” ugovor jer su plaćanja išla preko Akademije. To je bio presedan u načinu rada u Majstorskoj. Na projektu je radila Radna grupa pod mojim vodstvom (Ognjen Čaldarević, Ratko Miličević, Zoran Roca, Filka Vigna, Mila Zlatić).
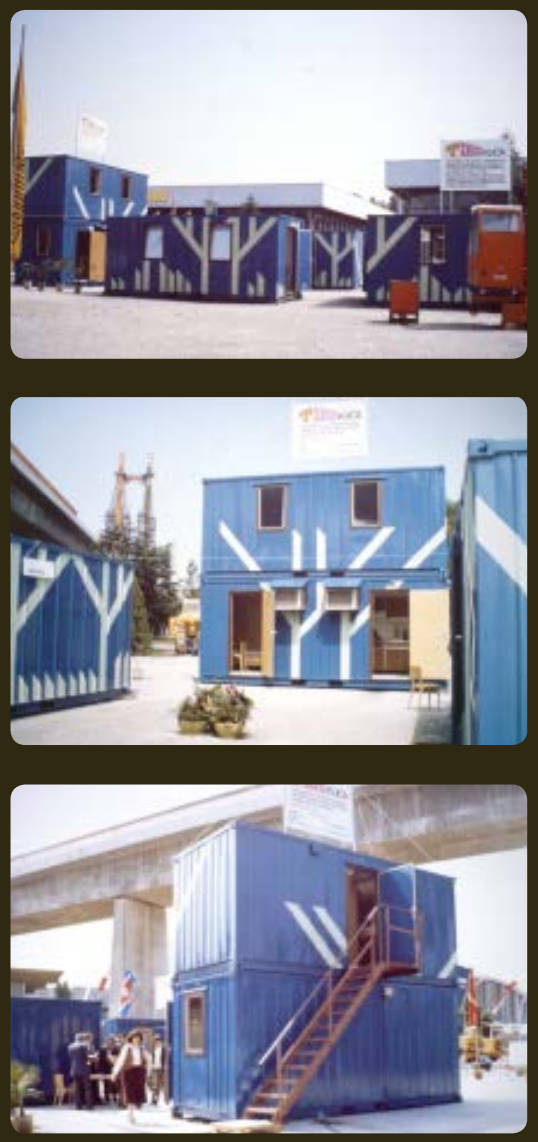

Sl. 8 Izlaganje TIBO kuće na sajmu Inova u Rijeci, 1977 . $\uparrow$ 
Realizacija projekta TIBO trajala je godinama, ali mi više s njim nismo imali veze. Ne znam točno do kada se proizvodio naš program i koliko su raznih modula proizveli i prodali. Vidim tek da je 2019. godine izašla obavijest da se našao kupac za bivši tvornički kompleks TIBO-a u Matuljima. To je zagrebačka tvrtka M.M.A. poslovanje, koja je u trećem krugu elektroničke dražbe ponudila deset milijuna kuna za ovaj 43000 četvornih metara veliki kompleks zemljišta i hala bivše tvornice brodske opreme.

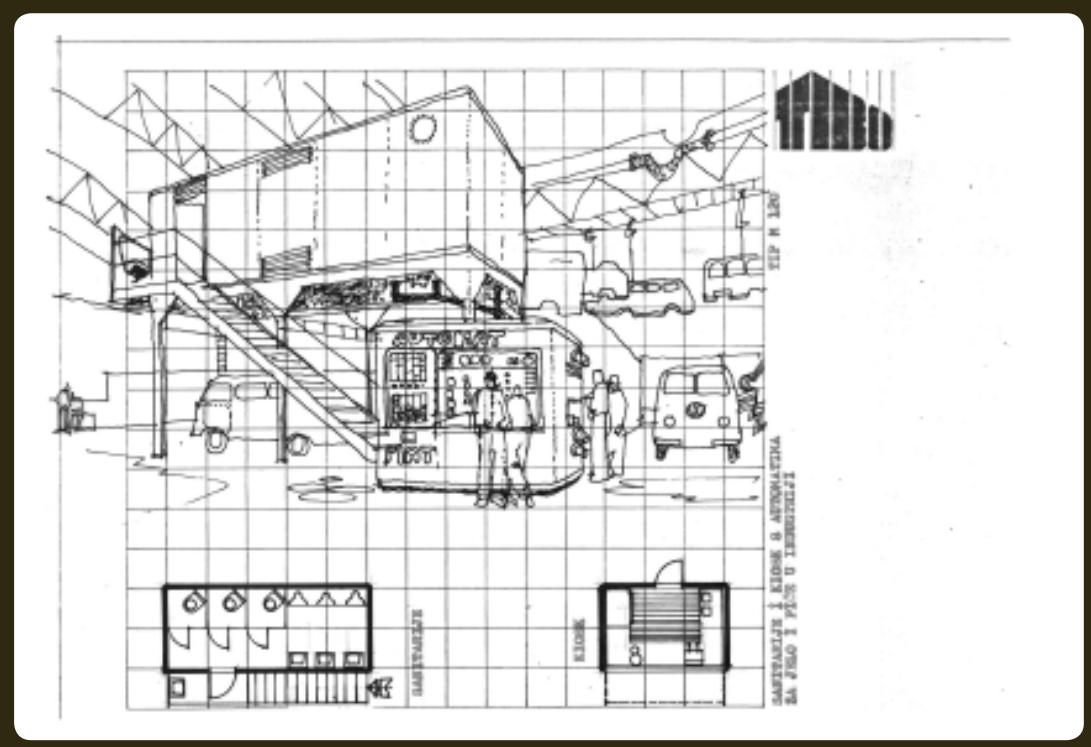

Sl. 9a Majstorska radionica profesora Drage Galića, Primjeri korištenja TIBO kuće u industriji-sanitarije

i kiosk s automatima za jelo i piće, I977.

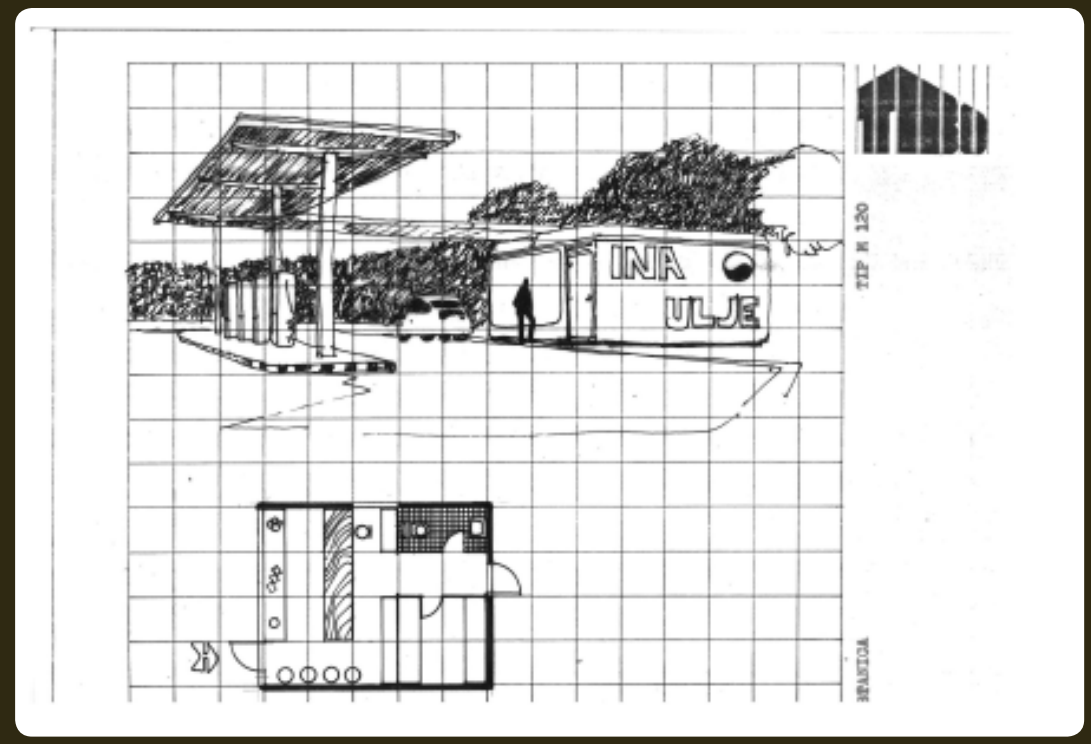

Sl. 9b Majstorska radionica profesora Drage Galića, Primjeri korištenja TIBO kuće—benzinska stanica, I977. 
Puno godina kasnije od vremena realizacije kontejnerskih objekata u Kumrovcu i začetaka programa TIBO, pretražujući nešto po internetu pronašao sam zanimljiv podatak. Kontejneri su postali popularni nakon Drugoga svjetskog rata. Prve modele koji bi se mogli prenijeti s motornih vozila na željeznicu ili na more bez utovara odnosno istovara sadržaja razvio je 1950. godine Malcolm Macklin. Prvi spomen o mogućnosti upotrebe proizvoda kao privremenog smještaja nalazi se u arhivu američke vojske, u dokumentu iz 1977. godine. Deset godina kasnije, 1987., Philip Clark podnio je zahtjev za patent, a američki arhitekt predložio je izgradnju stambenog prostora od ambalaže za višekratnu upotrebu.

Tad sam shvatio da su objekti iz Spomen-parka Kumrovec možda prva primjena kontejnera na svijetu izvan njegove standardne namjene, za prijevoz robe. Ne znam koliko su vremena kontejneri s javnim WC-om, info-punktom, snack-barom i svlačionicama uz sportske terene u Kumrovcu bili u upotrebi. Danas ih možda više nema, a tko se time okoristio, ne znam. Kad bih to znao, predložio bih da se ti kontejneri, ili barem neki od njih, prenesu u zagrebački Tehnički muzej kao prvi, ili jedan od prvih, primjera kontejnerske arhitekture na svijetu realiziran deset godina prije Clarkova zahtjeva za patent. Meni takvo što nikada nije palo na pamet.

Da se vratimo na početak, tj. povodu ovoga teksta-potresu na Baniji. Kako bi se danas trebalo ponašati u tom konkretnom slučaju u 21. stoljeću? Ja bih osobno „napao” svim sredstvima, pogotovo donacijama, ma kakve bile. Važno je da se ljudi sklone u najkraćem mogućem vremenu i imaju osnovni komfor. To je slična metoda koju smo predložili još 1978. godine u spomenutoj studiji Grad za rušenje. Da smo tada na taj način sanirali zagrebačku suburbiju, njezini bi stanovnici mogli čekati buduću planiranu namjenu. Ta bi sanacija ujedno pokazala da je daleko manje objekata potrebno rušiti nego što se to predlagalo velebnim urbanističkim planovima. Jedan je od njih onaj za Trnje iz 1965. godine. Vizija (urbanistički plan) Trnja, tj. Zagreba podrazumijevala je toliku količinu gradnje koju vjerojatno tada ne bi mogla realizirati ni cijela Jugoslavija u roku od deset godina. Urbanističke fantazije. Pa naš poznati urbanist Radovan Miščević u poratnim godinama nakon Drugoga svjetskog rata predlagao je grad koji bi se prostirao od Zaboka do Oroslavlja kao jedna aglomeracija! U cijelom Zagorju nije bilo stanovnika koji bi mogli napuniti taj grad.

Pitanje Banije nije izgradnja stambenih objekata, nego nešto drugo. A što je to drugo, svi znamo. Dosta je bilo Radićevih naselja, pokoj mu duši. 
Sl. Io Majstorska radionica profesora Drage Galića, Studija Vrbici-projekt sanacije stambene jedinice u naselju Vrbik X u Zagrebu, I977.
Sl. II Tvornica industrijske i brodske opreme „3. maj“, TIBO kuća Beta-katalog komponenata i dodatne vanjske opreme

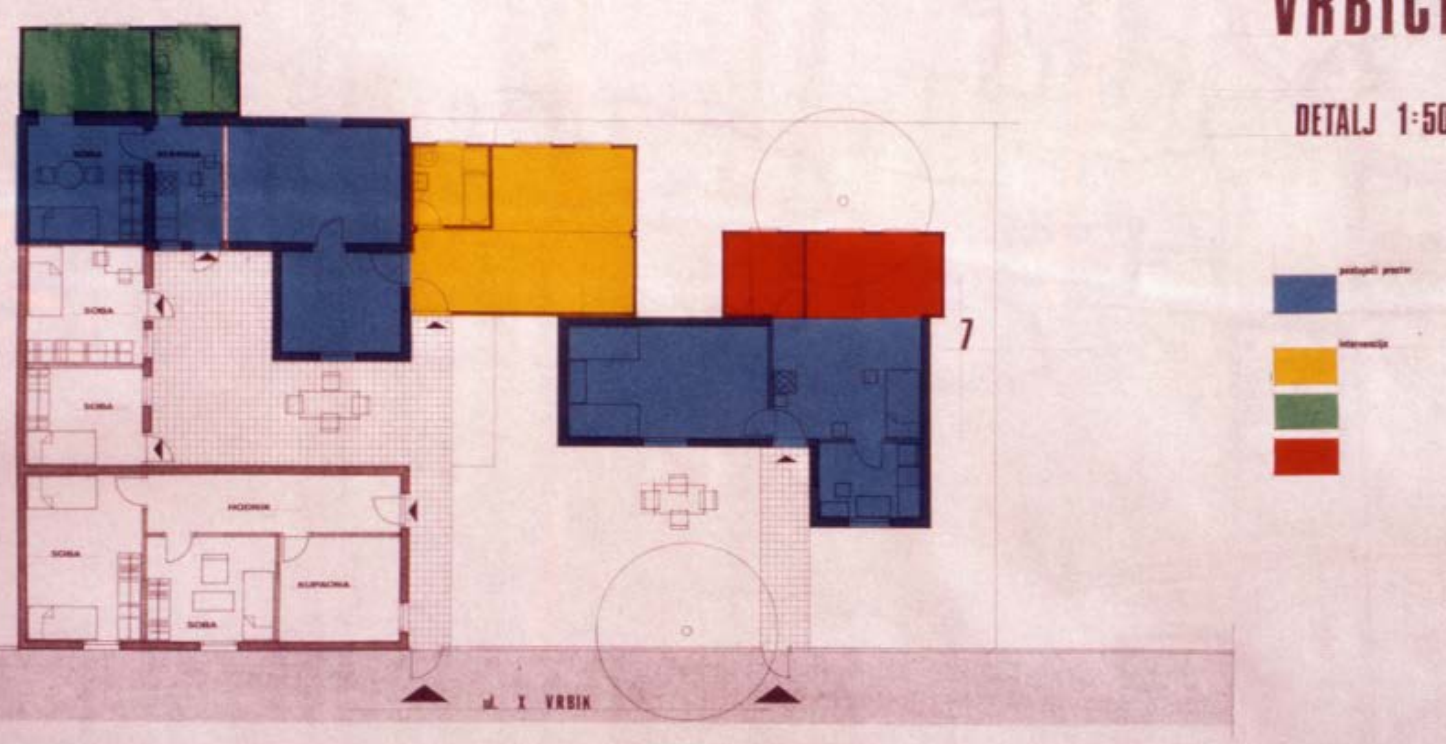



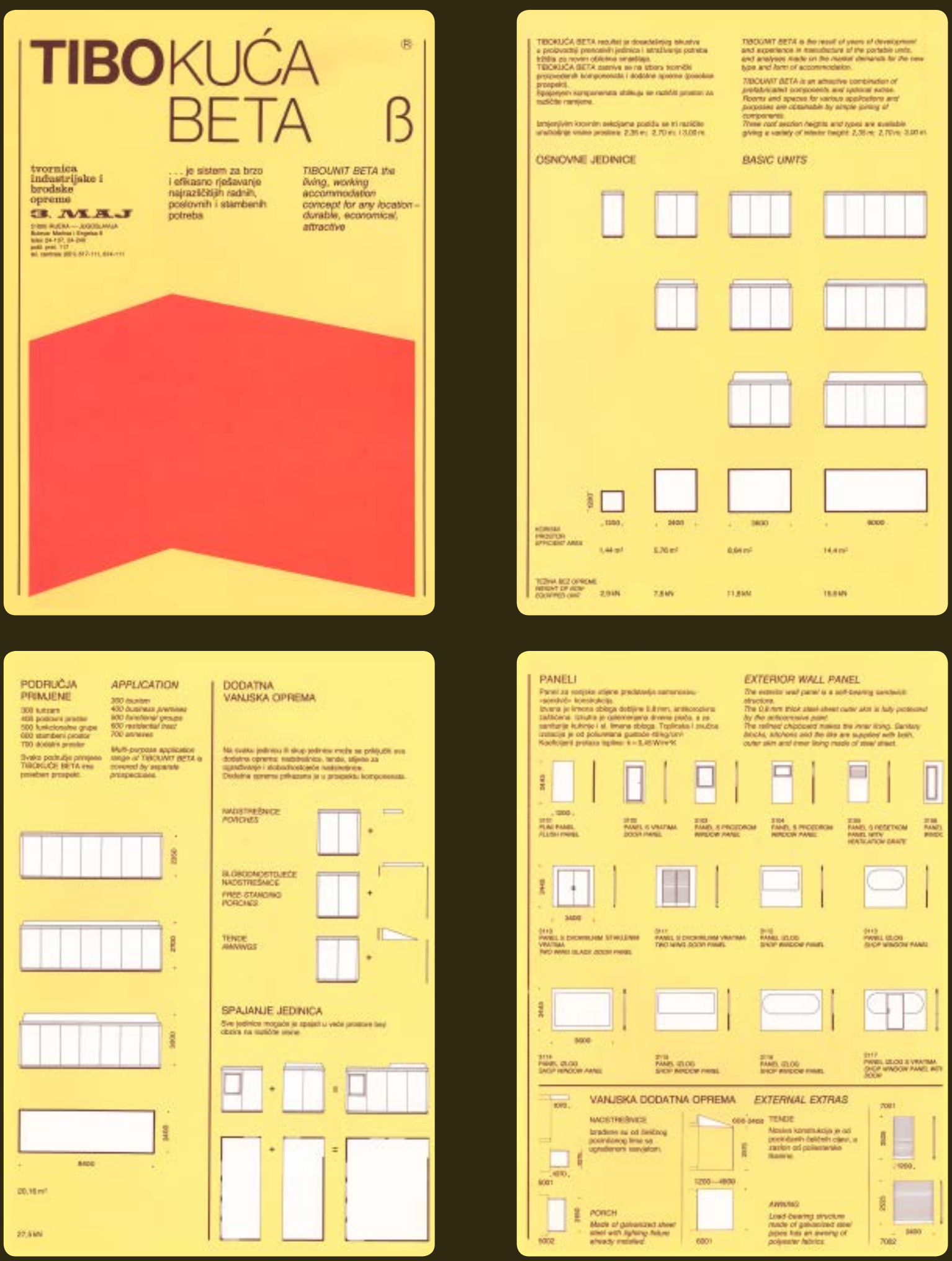